\title{
Tobacco Snuff Induced Comparative Weight Changes and Notable Physical Observations in Adults Albino Wistar Rats
}

\author{
Chima Innocent Ugbor ${ }^{1, ~ *, ~ C h i d i e b e r e ~ C y p r i a n ~ V i t u s ~ E l o k a ~}{ }^{1}$, Charles Ikechukwu Ezema ${ }^{2}$, \\ Uchechukwu Anthonia Ezeugwu², Benson Eihebholoria Omijie ${ }^{3}$, Solomon Nwanze Ekoh ${ }^{4}$, \\ Basil Nnaemeka Obodo ${ }^{1}$, Kenneth Emeka Udeme ${ }^{5}$ \\ ${ }^{1}$ Department of Medical Laboratory Science, Faculty of Basic Medical Sciences, Ambrose Alli University, Ekpoma, Nigeria \\ ${ }^{2}$ Department of Medical Rehabilitation, Faculty of Health Sciences and Technology, College of Medicine, University of Nigeria, Enugu \\ Campus, Nigeria \\ ${ }^{3}$ Department of Chemical Pathology, Irrua Specialist Teaching Hospital, Irrua, Nigeria \\ ${ }^{4}$ Department of Chemical Pathology, Medical Laboratory services, Enugu State University Teaching Hospital, Parklane, Enugu, Nigeria \\ ${ }^{5}$ National Obstetric Fistula Center, Abakaliki, Nigeria
}

Email address:

i.chimaresearch2@gmail.com (C. I. Ugbor)

*Corresponding author

\section{To cite this article:}

Chima Innocent Ugbor, Chidiebere Cyprian Vitus Eloka, Charles Ikechukwu Ezema, Uchechukwu Anthonia Ezeugwu, Benson Eihebholoria Omijie, Solomon Nwanze Ekoh, Basil Nnaemeka Obodo, Kenneth Emeka Udeme. Tobacco Snuff Induced Comparative Weight Changes and Notable Physical Observations in Adults Albino Wistar Rats. European Journal of Clinical and Biomedical Sciences.

Vol. 7, No. 2, 2021, pp. 21-26. doi: 10.11648/j.ejcbs.20210702.11

Received: August 28, 2020; Accepted: October 13, 2020; Published: March 22, 2021

\begin{abstract}
In Nigeria, tobacco snuff is the powdered form of smokeless tobacco blended with potash as its main additive. It has been discovered to have several adverse health effects, though perceived by many as safe. In this eight-week study, the effect of tobacco snuff consumption on body weight, physical observation and growth performance of Wistar rats were investigated. This study involved (42) Adult Wistar rats weighing 150-300g. They were divided into groups of tests and control, group A serving as control, while groups B, C and D of 12 Wister rats each served as the test groups. The test groups were further divided into subgroups (1, 2, 3 and 4) representing four experimental phases of 2, 4, 6 and 8 weeks respectively. The rats were fed with varying doses of tobacco snuff, while the control group (A) received feed pallets and water ad libitum. Throughout the study, serial physical and behavioural changes of the rats were recorded as well as the body weights of the rats before sacrifice. Results showed statistically significant weight changes in the test groups throughout the study period as compared with the control. On growth performance, there was an average daily growths increase in the control but decreased in the test groups in a dosage and duration dependent manner. Our findings however, indicate that tobacco snuff has the potentials of body weight reduction and could induce severe growth retardation with adversities.
\end{abstract}

Keywords: Tobacco Snuff, Additives, Weight Changes, Physical Observations, Rat

\section{Introduction Ugbor et al. [1] Stated That}

With regards to the existing information (s) on tobacco snuff, some studies have advocated its use as safe under certain conditions, however others stated in the contrary. Based on this, Tuner as reported by Ugbor et al [1] stated that snuff has become quite popular medication for pain and aches. Although, reports have it that tobacco snuff has been implicated with several systemic and organ damage in which [2] reported induced alterations in renal functions. Owing to the strive by scientists to discover ways to reduce systemic health challenges through food fortifications, [3, 4] stated that the human body system itself has a measure of developing a defensive mechanism that enables the storage of energy thereby increasing the chance of survival during food scarcity/shortage and prolonged starvation and this is done by 
storing the excess food in form of fat.

Regrettably, this may lead to excessive weight gain which is attributed to diverse health complication [5]. According to [6-8] weight complication is reported as a leading preventable cause of death worldwide with increasing prevalence in adults and children. Seidell as reported by [3] stated that overweight and obesity is passive as an alien occurrence or a more western occurrence which is not common in developing countries but it is fast becoming our next door neighbour. However, researchers have maintained that insufficient nutrients to maintain bodily functions are associated with malnutrition, which may result from faulty nutrition, poor diet, or excessive consumption of particular foods or spices. Some consumable substances and there additives moreover have been seen to alter body weight, thereby negatively influence the natural defence mechanism for energy storage making life vulnerable.

The substance of interest in this study is tobacco snuff and its additive 'potash'. Tobacco snuff is the powdered form blended with potash as the main additive in Nigeria $[9,1]$. It contains nicotine, potent tobacco-specific carcinogen 4(methylnitrosamino)-1-(3-pyridyl)-1-butanone), 4-methylnitrosamino)-4-(3-pyridyl)-butanal (NNA), and Nnitrosonornicotine [10], heavy metals (Cadmium (Cd), mercury $(\mathrm{Hg})$ etc) $[11,12]$ and 23 polycyclic aromatic hydrocarbons [13] as its major constituent. Interestingly, several scientific investigations have exposed the inherent dangers in tobacco snuffconsumption which raised the need to draw the attention of consumers to the hazardous effects and subsequent health implications of excessive tobacco snuff consumption. Therefore, this study investigates the effect of tobacco snuff consumption on body weight and notable physical changes. In addition, growth performance status was also observed in this study.

\section{Materials and Methods}

\subsection{Experimental Animals}

Adult Albino Wister rats $(n=42)$ of comparable sizes and weighing (150-300g) were bought from the animal farm of Anthonio Research Center, Ekpoma, Edo state, Nigeria. They were transferred to the experimental site of Anthonio Research Center at No. 40 Ujoelen Extension, Ekpoma, Edo State, Nigeria where they were allowed two weeks of acclimatization in a wooden wire mesh cages under standard laboratory procedure [1].

\subsection{Ethics on the Use of Animals in Experimental Studies}

The experimental protocols were according to our Institutional guidelines as well as internationally accepted practices for use and care of laboratory animals as contained in US guidelines $[1,14]$.

\subsection{Substance of Study}

The substance of study (Dry leaves of tobacco and potash) were purchased from Ogbete main market, Enugu state,
Nigeria. After which, the tobacco leaves were identified and authenticated by a botanist in the Department of Botany, Ambrose Alli University, Ekpoma, Edo state, Nigeria [1].

\subsection{Substance Preparation}

Following scientific procedure, the tobacco leaves and potash were blended into powder using a mortar and iron pestle and then stored prior to the study. In other to obtain graded doses, the blended tobacco leaves with potash were weighed using an electronic balance (Denver Company, USA, 200398. IREV. CXP-3000). For the purpose of this study, feed pellets and graded doses of tobacco snuff were prepared as described by $[15,1]$.

\subsection{Animal Grouping}

The study involved four experimental phases and groups and these include: phase 1, phase 2, phase 3 and phase 4 . The phases lasted for a corresponding period of 2, 4, 6 and 8 weeks. The rats were divided into four groups (A, B, C and D) with group A serving as control, while groups B, C and D served as the test groups. The test groups were further divided into four groups (B1, C1, D1; B2, C2, D2; B3, C3, D3; and B4, C4, D4) representing four experimental phases/duration (2, 4, 6 and 8 weeks) and varying doses of tobacco dust mixed with potash respectively. At the end of 2 , 4, 6 and 8 weeks respectively, 3 randomly selected rats from the groups will be weighed as well as notable observations taken before experimental sacrifice [1].

\subsection{Study Duration}

The five months experimental period involved preliminary studies, animal acclimatization, substance procurement (tobacco leaves and potash), actual animal experiment and evaluation of results. However, the actual administration of tobacco snuff to the test animals lasted for 8 weeks.

\subsection{Substance Administration}

Phase 1: Group A (control) received $100 \mathrm{~g}$ of feed and distilled water only whereas test group $\mathrm{B}, \mathrm{C}$ and $\mathrm{D}$ received $97.12 \mathrm{~g}$ of feed, $2.4 \mathrm{~g}$ of tobacco dust and $0.48 \mathrm{~g}$ of potash; $94.24 \mathrm{~g}$ of feed, $4.80 \mathrm{~g}$ of tobacco dust and $0.96 \mathrm{~g}$ of potash; and $91.36 \mathrm{~g}$ of feed, $7.20 \mathrm{~g}$ of tobacco dust and $1.44 \mathrm{~g}$ of potash respectively. Each test group received distilled water ad libitum.

Phase 2: Group A (control) received $75 \mathrm{~g}$ of feed and distilled water only, whereas test group $\mathrm{B}, \mathrm{C}$ and $\mathrm{D}$ received $72.84 \mathrm{~g}$ of feed, $1.8 \mathrm{~g}$ of tobacco dust and $0.36 \mathrm{~g}$ potash; $70.68 \mathrm{~g}$ of feed, $3.6 \mathrm{~g}$ of tobacco dust and $0.72 \mathrm{~g}$ of potash; and $68.52 \mathrm{~g}$ of feed, $5.4 \mathrm{~g}$ of tobacco dust and $1.08 \mathrm{~g}$ of potash respectively. Each test group received distilled water ad libitum.

Phase 3: Group A (control) received $50 \mathrm{~g}$ of feed and distilled water only, whereas test group B3, C3 and D3 received $48.56 \mathrm{~g}$ of feed, $1.2 \mathrm{~g}$ of tobacco dust and $0.24 \mathrm{~g}$ potash; $47.12 \mathrm{~g}$ of feed, $2.4 \mathrm{~g}$ of tobacco dust and $0.48 \mathrm{~g}$ of potash; and $45.68 \mathrm{~g}$ of feed, $3.6 \mathrm{~g}$ of tobacco dust and $0.72 \mathrm{~g}$ of potash respectively. Each test group received distilled water 


\section{ad libitum}

Phase 4: Group A (control) received 25g of feed and distilled water only, whereas test group B4, C4 and D4 received $24.28 \mathrm{~g}$ of feed, $0.6 \mathrm{~g}$ of tobacco dust and $0.12 \mathrm{~g}$ potash; $23.56 \mathrm{~g}$ of feed, $1.2 \mathrm{~g}$ of tobacco dust and $0.24 \mathrm{~g}$ of potash; and $22.84 \mathrm{~g}$ of feed, $1.8 \mathrm{~g}$ of tobacco dust and $0.36 \mathrm{~g}$ of potash respectively. Each test group received distilled water ad libitum.

The concentrations of tobacco snuff used in this study were deduced from the work of [16] while that of potash was deduced from [1].

\subsection{Data Analysis}

The results collected were subjected to statistical analysis using SPSS (version 18). The test groups' values were compared with the control using one way ANOVA (LSD) at $95 \%$ level of confidence.

\section{Results}

In table 1 and 2, physical observations showed relative fur color changes from normal to dirty brown as observed among the test groups throughout the experimental period. Feed consumption was high among the control group, while average feed rejection and excessive water intake were noticeable in all the test groups. However, throughout the experimental period, litter delivery was observed in both the control and the test groups except group $\mathrm{C}$ that manifested preterm delivery. Physically, the control rats appear active, whereas, the test groups both showed hyperactive and docile characteristics during the study period. Severely, the test group rats appeared skinny as the duration of the experiment progresses as compared to the control group which looks robust and fatty. It was also observed that the test group rats manifested altered respiratory rate. All other observations and behavioural changes were noted and tabulated (see tables 1 and 2).

Table 1. Notable physical observations and average feed consumption of rats fed with graded doses of tobacco snuff for 2 weeks and 4 weeks.

\begin{tabular}{|c|c|c|c|c|c|c|c|c|}
\hline \multirow{2}{*}{ Observations } & \multicolumn{2}{|l|}{ Control A } & \multicolumn{2}{|l|}{ Group B } & \multicolumn{2}{|l|}{ Group C } & \multicolumn{2}{|l|}{ Group D } \\
\hline & 2weeks & 4weeks & 2weeks & 4weeks & 2weeks & 4weeks & 2weeks & 4weeks \\
\hline Fur colour change & - & - & - & + & + & + & + & + \\
\hline Behavioral changes & - & - & + & + & + & + & + & + \\
\hline Skin changes & - & - & - & + & + & + & + & + \\
\hline Eye colour changes & - & - & + & + & + & + & + & + \\
\hline Growth status & NG & NG & $\mathrm{R}$ & SR & $\mathrm{R}$ & SR & $\mathrm{R}$ & SR \\
\hline Diarrhea/weakness & - & - & - & - & - & - & - & - \\
\hline Quick response to Water (dehydration) & - & - & + & + & ++ & ++ & ++ & ++ \\
\hline Feed rejection & - & - & - & + & + & + & + & + \\
\hline Birth & + & + & + & - & - & - & - & + \\
\hline Physical agility & A & A & A & HA & HAD & HAD & HAD & HAD \\
\hline Inability to move/seizure & - & - & - & - & - & - & - & - \\
\hline Preterm birth & - & - & - & - & - & - & - & - \\
\hline Decreased Mating & - & - & + & + & + & + & + & + \\
\hline
\end{tabular}

Key: Notable growth (NG), Retardation (R), Severe retardation (SR), Active (A), Hyper active (HA) and Hyper active/ Docile (HAD), $+=$ Present, $-=$ Absent

Table 2. Notable physical observations and average feed consumption of rats fed with graded doses of tobacco snuff for 6 weeks and 8 weeks.

\begin{tabular}{|c|c|c|c|c|c|c|c|c|}
\hline \multirow{2}{*}{ Observations } & \multicolumn{2}{|l|}{ Control A } & \multicolumn{2}{|l|}{ Group B } & \multicolumn{2}{|l|}{ Group C } & \multicolumn{2}{|l|}{ Group D } \\
\hline & 6weeks & 8weeks & 6weeks & 8weeks & 6weeks & 8weeks & 6weeks & 8weeks \\
\hline Fur colour change & - & - & + & + & + & + & + & + \\
\hline Behavioral changes & - & - & + & + & + & + & + & + \\
\hline Skin changes & - & - & + & + & + & + & + & + \\
\hline Eye colour changes & - & - & + & + & + & + & + & + \\
\hline Growth status & $\mathrm{NG}$ & NG & SR & SR & SR & SR & SR & SR \\
\hline Diarrhea/weakness & - & - & - & - & - & - & - & - \\
\hline Quick response to Water (dehydration) & - & - & ++ & ++ & ++ & +++ & +++ & +++ \\
\hline Feed rejection & - & - & + & + & + & + & + & + \\
\hline Birth & + & - & - & - & - & - & - & - \\
\hline Physical agility & A & A & HA & HA & HAD & HAD & HAD & HAD \\
\hline Inability to move/seizure & - & - & - & - & - & - & - & - \\
\hline Preterm birth & - & - & - & - & + & - & - & - \\
\hline Decreased Mating & - & - & + & + & + & ++ & ++ & ++ \\
\hline Altered respiratory rate & - & - & - & + & + & + & + & ++ \\
\hline
\end{tabular}

Key: Notable growth (NG), Retardation (R), Severe retardation (SR), Active (A), Hyper active (HA) and Hyper active/ Docile (HAD), $+=$ Present, $-=$ Absent

The body weight changes recorded for control and test groups after acclimatization and during the experiment $(2,4$,
6 and 8 weeks treatment periods) are shown in table 3 . There was severe weight loss in the entire test groups as compared 
to the control group which showed progressive weight gain throughout the experiment. The body weight changes of all the test groups were statistical significant $(p \leq 0.05)$ when compared with the values obtained after acclimatization.

Table 3. Body weight changes of rats fed with graded doses of tobacco snuff.

\begin{tabular}{llll}
\hline Stages of weight measurement & Control Group A & Test groups & C \\
\cline { 3 - 4 } & & B & $212.50 \pm 25.00^{\mathrm{a}}$ \\
\hline Weight. after Acclimatization & $208.33 \pm 25.82^{\mathrm{a}}$ & $191.67 \pm 28.87^{\mathrm{a}}$ & $118.73 \pm 17.32^{\mathrm{b}}$ \\
Weight. At the end of 2wks & $241.67 \pm 43.78^{\mathrm{a}}$ & $145.42 \pm 14.23^{\mathrm{ab}}$ & $214.58 \pm 16.72^{\mathrm{a}}$ \\
Weight. At the end of 4wks & $244.67 \pm 45.67^{\mathrm{a}}$ & $121.44 \pm 17.81^{\mathrm{b}}$ & $96.88 \pm 13.35^{\mathrm{b}}$ \\
Weight. At the end of 6wks & $305.00 \pm 10.00^{\mathrm{a}}$ & $120.83 \pm 20.35^{\mathrm{b}}$ & $95.80 \pm 13.07^{\mathrm{b}}$ \\
Weight at the end of 8 wks & $274.17 \pm 51.03^{\mathrm{a}}$ & $133.67 \pm 16.17^{\mathrm{ab}}$ & $100.78 \pm 9.38^{\mathrm{b}}$ \\
\hline
\end{tabular}

All the values of the test groups with different subscript from the controls are significantly different at $\mathrm{p}<0.05$. Key: weeks (wks)

Table 4 however, shows the growth performance and feed conversion rate (FCR) of rats fed with graded doses of tobacco snuff. Weight gain (WG), percentage weight gain $(\% \mathrm{WG})$ and the average daily growth (ADG) were also recorded. While control (group A) showed an increased body weight gain with increased ADG throughout the period of the experiment, the entire test groups suffered a percentage weight loss of $-24.13,-44.12$ and $-34.25 \%$ respectively. The ADG of all the test groups showed severe but significant decreases compared to the control. As regards the feed conversion rate, feed quantity adjustments were done bearing in mind the research design. The feed quantity was adjusted based on the number of rats remaining after experimental sacrifice of 3 randomly selected rats from each group except the control that was sacrifice at the end of the study. The differences observed in $\mathrm{WG}, \% \mathrm{WG}, \mathrm{ADG}$ and FCR among the test groups were dosage and duration dependent.

Table 4. Growth performance and feed conversion of rats fed graded doses of tobacco snuff.

\begin{tabular}{|c|c|c|c|c|c|}
\hline \multirow{2}{*}{ PARAMETERS } & & \multirow{2}{*}{$\begin{array}{l}\text { CONTROL A } \\
(n=6)\end{array}$} & \multirow{2}{*}{$\begin{array}{l}B \\
(n=12)\end{array}$} & \multirow{2}{*}{$\begin{array}{l}C \\
(n=12)\end{array}$} & \multirow{2}{*}{$\begin{array}{l}D \\
(n=12)\end{array}$} \\
\hline & & & & & \\
\hline \multirow[t]{4}{*}{ Weight gain } & 2 & 33.34 & -46.25 & -93.77 & -73.50 \\
\hline & 4 & 36.33 & -70.23 & -115.62 & -113.80 \\
\hline & 6 & 96.67 & -70.84 & -116.70 & -117.91 \\
\hline & 8 & 65.84 & -58.00 & -110.00 & -114.58 \\
\hline \multirow[t]{4}{*}{$\%$ Weight gain } & 2 & 16.00 & -24.13 & -44.12 & -34.25 \\
\hline & 4 & 17.44 & -36.64 & -54.40 & -53.03 \\
\hline & 6 & 46.40 & -37.01 & -54.91 & -54.95 \\
\hline & 8 & 31.60 & -30.26 & -51.76 & -53.40 \\
\hline \multirow[t]{4}{*}{$\mathrm{ADG}(\mathrm{g})$} & 2 & 2.38 & -3.30 & -6.70 & -5.25 \\
\hline & 4 & 2.60 & -5.02 & -8.26 & -8.13 \\
\hline & 6 & 6.91 & -5.06 & -8.34 & -8.42 \\
\hline & 8 & 4.70 & -4.14 & -7.90 & -8.18 \\
\hline \multirow[t]{3}{*}{ FCR } & 2 & 2.99 & -0.23 & -0.29 & -0.49 \\
\hline & 4 & 2.06 & -0.07 & -0.13 & -0.12 \\
\hline & 8 & 0.37 & -0.02 & -0.06 & -0.05 \\
\hline
\end{tabular}

Key: Weight gain (WG), percentage weight gain (\%WG) and the average daily growth (ADG), feed conversion rate (FCR).

\section{Discussions}

Physical observations of obvious signs and symptoms is the first step to proper diagnosis and this study showed the observed effects of tobacco snuff consumption. More and more the observed changes such as colour change (fur, eye and skin), Behavioural changes, Skin changes, dehydration, feed rejection, Preterm birth, Decreased Mating, altered respiratory rate and altered animal activity and growth, emphatically suggests that tobacco snuff has potentials to alter physiological processes that may result in undesirable conditions. In effect, the observed skin changes and growth retardation confirmed the findings of Oyeleke as reported by [1] that chronic natron (potash) ingestion revealed severe growth retardation, skin changes and diarrhoea. This explains the hypertonic and retardation capacity of tobacco snuff and its additive that proves to be severely harsh on the skin tissue and growth factors. A similar study reported that moderate intake of natron had adverse effects on growth rate and blood indices in rats and of recent, [17] reported decreased protein synthesis induced by tobacco snuff and this could generally result to growth retardation observed in this study.

Existing literatures have it that smokeless tobacco contains substantial quantities of licorice that is known to cause excessive accumulation of mineralocorticoids, which may result in hypertension, sodium retention, hypokalaemia and myalgia and this may be the cause of the observed dehydration and feed rejection in this study. Also knowing the mechanism of sodium induced dehydration, smokeless tobacco salt in addition causes damage to the gastric epithelium, providing favorable conditions for the occurrence of mutations [18] and it has been established that there is a positive correlation between daily salt intake and gastric cancer incidence. In addition, the feed rejection could be attributed to the taste of 
tobacco snuff which is known to be better.

Furthermore, the observed preterm birth and decreased mating demonstrates the deleterious effects of tobacco snuff on the reproductive functions. Preterm birth is characteristically one of the major causes of low birth weight and its many associated complications. [19] Reported that smokeless tobacco use by pregnant women reduces birth weight and increases the number of low birth weight babies and also shortens the gestational period with increase in the number of preterm deliveries. Also on fetus, adversely nicotine targets specific neurotransmitter receptors in the fetal brain and may affect neural cell proliferation and differentiation, leading to shortfalls in the number of cells and altered synaptic activity. The consequences of these changes include neurological and cognitive deficits, and nicotine dependence in the offspring. These changes may occur even after a long period of early childhood normality, becoming evident in late childhood and even during the adolescent period [20]. In the same vein, [21] revealed in an experiment of pure nicotine ingestion that nicotine reduces libido in male rats and this confirms the decreased birth number observed among the test groups in the study. Knowing that smokeless tobacco is not safe and it has innate and acquired deleterious effects, [22] reported an association between smokeless tobacco use and chronic bronchitis with lower peak expiratory flow rate and this confirmed the observed respiratory alterations in the study.

Like Yaji and Xylopiaaethiopica leave, tobacco snuff showed potentials of body weight reduction when the test groups were compared with the control. Although [23, 24] reported that Yaji induced low body weight could be due to the repulsive effect of the pungent nature of its spices such as red pepper, which usually leads to reduced feeding. But in the contrary, the feed rejection rate observed in the study was a little high in the beginning and decreases as duration increases. Also the feed consumption rate was low at first, but increases as duration increases and these observations affirms the potentials of tobacco snuff in inducing low body weight.

In addition, it was observed that the control group had the best growth response (combination of $\mathrm{WG}, \% \mathrm{WG}$ and $\mathrm{ADG}$ ) throughout the study. The decrease in growth performance observed among the test groups at high FCR appeared to have affected the body weight negatively; and the degree to which this factor contributed to this effect is dose dependent. This agrees with the findings by [25] on the effect of Xylopiaaethiopicaleaves on body weight and growth performance. Literally, despite the negative effects of tobacco snuff consumption, its resultant effect on body weight showed green light toward weight management, although scientific evidences showed that the deleterious effects overweighs the possible positive impact, hence necessary precautions.

\section{Conclusion}

It was concluded from the present study findings that tobaccos snuff has severe adverse effect on body weight, physical observation and growth performance. This current study showed that tobacco snuff affects the body's capacity to synthesise growth factors thereby causing serious growth retardation and even preterm birth. Its deleterious effects were demonstrated by respiratory alteration and decrease in growth performance observed that were dosage and duration dependent.

\section{Significant Statement}

This study found the weight reduction capacity of tobacco snuff as a green light toward body weight management but the deleterious effects overweighs the possible positive impact. Since consumption is on the increase, this result exposes the serious danger behind what is commonly taken as a safe substitute for cigarette smoking and recreational drug. Given that it compromises growth performance, the findings shows nutritional chain deformity, hence, urgent public health awareness of this hidden danger of tobacco snuff consumption.

\section{Author Contributions}

This study was carried out by all authors and they were all involved from conception and design, data analysis and interpretation of data, drafting of article to final approval of the version to be published.

\section{Acknowledgements}

The authors acknowledge the assistance provided by the staff of Anthonio Research Center, Ekpoma, Edo State, Nigeria, for there unconditional help during this study.

\section{References}

[1] Ugbor CI, Okogun GRA, Okonkwo LO, Eze NC, Asogwa BE, Ebo JO, Maduagwuna GN, Ekoh SN. The Effect of Tobacco Snuff Consumption on Liver Enzymes. Int. J. Herbs. PharmacolRes2013b; 2: 20-27.

[2] Okonkwo LO, Dada FL, Ugbor CI et al., Tobacco Induced Renal Function Alterations InWistar Rats: An 8 Weeks Study. Inter. J. Herbs. Pharmacol Res 2013; 2: 29-35.

[3] Bankole JK, Okon AU, Okpidu EE, Okhai O. Idehen C, Iyiola $\mathrm{S}$ et al., Weight changes induced by ingestion of alomo bitters (a combination of herbal constituents): experimental study on wistar rats. IJCR 2012; (1): 35-39.

[4] Keith, S. 2007. Appetite, weight loss: How spices can help obesity. Available from: http://ezinearticles.com/?expert=Keith_Scott_M.D. $\quad\left[10^{\text {th }}\right.$ March 2019].

[5] Akpamu U, Nwaopara AO, Izunya AM, Oaikhena GA, Okhiai $\mathrm{O}$, Idonije $\mathrm{OB}$ et al., A comparative study on weight changes in rats fed with diet containing Yaji, Yaji-additives and Yajispices. Biology and Medicine 2011; 3: 6-15.

[6] Barness LA, Opitz JM, Gilbert-Barness E, Obesity: genetic, molecular, and environmental aspects. A J Med Gen 2007; 143A: 3016-34. DOI: 10.1002/ajmg.a.32035. 
[7] Kopelman P and Caterson I. An overview of obesity management. In: Peter G. Kopelman, Ian D. Caterson, Michael J. Stock, William H. Dietz (2005). Clinical obesity in adults and children: In Adults and Children. Blackwell Publishing; 2005. Pp. 319-326. ISBN 978-1-4051-1672-5.

[8] World Health Organization 2000. Technical report series 894: Obesity: Preventing and managing the global epidemic. Geneva: World Health Organization. ISBN: 92-4-120894-5. Available from: http://whqlibdoc.who.int/trs/WHO_TRS_894 (part1) [ $4^{\text {th }}$ March 2019].

[9] Ureme SO, Ibeagha ID, Maduka IG, Ibeagbulam OG. The concentrations of methaemoglobin, carboxyhaemoglobin and some ssshaematological parameters in tobacco snuff addicts in igbo of nigeria. Nig. J. Physiologi. Sci., 2007; 22: 27-30. https://www.ncbi.nlm.nih.gov/pubmed/18379614.

[10] Hecht SS, Carmella SG, Murphy SE. et al., Similar exposure to a tobacco-specific carcinogen in smokeless tobacco users and cigarette smokers. Cancer. Epidemiol. Biomarkers. Prev 2007; 16: 1567-72. DOI: 10.1158/1055-9965.EPI-07-0227.

[11] Addo MA, Gbadago JK, Affum HA, Adom T, Ahmed K, Okley GM. Mineral profile of ghanaian dried tobacco leaves and local snuff: A comparative study. J. Radioanal. Nuc. Chem 2008; 277: 517-24.

[12] Addo MA, Duodu OG, Affum HA, Gbadago JK, Darko EO. Coleman A. Determination of Minerals Profile in Ghanaian Local Snuffs and an Imported Snuff Using Instrumental Neutron Activation Analysis. Brit J Pharmacol Toxi 2011; 2: 293-301.

[13] Stepanov I, Peter W, Villalta A, Knezevich JJ, Dorothy H, Stephen SH. Analysis of 23 polycyclicaromatic hydrocarbons in smokeless tobacco by gas chromatography-mass spectrometry. Chem Res Toxicol 2010; 23: 66-73. doi: $10.1021 /$ tx900281u.

[14] NIH (National Institute of Health). 1992. Institutional animal care and use committee guidebook. NIH Publication, Washington D.C. USA. Government Printing Office. 92-3415. https://grants.nih.gov > grants > olaw > guidebook $\left[4^{\text {th }}\right.$ March 2019].

[15] Nwaopara AO, Akpamu U, Izunya AM. et al., The effect of Yaji-meat-sauce consumption on cerebellar neurons of white albino rats. Curr. Rese. J. Biol. Sci 2011; 3: 308-312.
[16] Bagchi M, Bagchi D, Hassoun EA. et al., Smokeless tobacco induced increases in hepatic lipidperoxidation, DNA damage and excretion of urinary lipid metabolites. Inter. J. Exp. Pathol 1994; 75: 197-202. https://www.ncbi.nlm.nih.gov/pmc/articles/PMC2001798/.

[17] Ugbor CI, Okonkwo LO, Okonkwo NL, Duhu NJ. Acute Effect of Tobacco Snuff Consumption on Plasma Total Protein, Albumin, Globulin and Fasting Blood Sugar Level in Rats. AJMH 2019; 15: 1-6. https://doi.org/10.9734/ajmah/2019/v15i330123.

[18] Sugimura T. Nutrition and dietary carcinogens. Carcinogenesis 2000; 21: 387-395. DOI: 10.1093/carcin/21.3.387.

[19] Gupta PC and Subramoney S. Smokeless tobacco use, birth weight, and gestational age: population based, prospective cohort study of 1217 women in Mumbai, India. BMJ 2004; 328: 1538. DOI: $10.1136 / \mathrm{bmj} .38113 .687882$.EB.

[20] Slotkin TA. Fetal nicotine or cocaine exposure: which one is worse? Pharm. Experi. Therap 1998; 285: 931-45. https://www.ncbi.nlm.nih.gov/pubmed/9618392.

[21] Oyeyipo IP, Raji Y, Emikpe BO, Bolarinwa AF. Effects of Nicotine on Sperm Characteristics and Fertility Profile inAdult Male Rats: A Possible Role of Cessation. J. Reprod. Infertil 2011; 201-207. https://www.ncbi.nlm.nih.gov/pubmed/23926503.

[22] Ayo-Yusuf OA, Reddy PS, Van de Borne BW. Association of snuff use with chronic bronchitis among South African women: implications for tobacco harm reduction. Tobacco Contro 2008; 17: 99-104. doi: 10.1136/tc.2007.022608.

[23] Agbo EG, Nwaopara AO, Festus OO, Odike MAC, Nosakhare IO. A Relative study on weight changes and notable physical observations in adults albino wistar rats fed with YAJI (A COMPLEX MEAT SAUCE). IJBAIR 2013; 2: 92-99.

[24] Oyewole IO, Mogaji ZJ, Awoyinka OA. Biochemical and Toxicological studies of aqueous extract of Tithoniadiversifolia (Hemsl.) leaves in Wistar albino rats. J. Medicin. Plants Res 2007; 1: 030-033.

[25] Obodo BN, Iweka FK, Obhakhan JO, Dada FL, Festus OO, Onoyovwi AO. Hepatic potentials of Xylopiaaethiopicaleaves in adult wistar rats. IJHPR 2013; 2: 36-41. https://www.ajol.info/index.php/ijhpr/article/view/106321. 